\title{
Rheological evaluation of industrial tomato in raw and processed condition
}

\author{
Tóth, A. R. ${ }^{1}$, Tóthné Bogárdi, A. ${ }^{2}$, Rubóczki, T. ${ }^{1}$ \& Takácsné Hájos, M. ${ }^{1}$ \\ ${ }^{1}$ University of Debrecen, Faculty of Agricultural and Food Sciences and Environmental Management, \\ Institute of Horticultural Science, 138. Böszörményi str., H-4032 Debrecen, Hungary \\ ${ }^{2}$ University of Debrecen, Faculty of Agricultural and Food Sciences and Environmental Management, \\ Institute of Food Science, 138. Böszörményi str., H-4032 Debrecen, Hungary \\ Author for correspondence: hajos@agr.unideb.hu
}

\begin{abstract}
Summary: Tomato (Lycopersicon esculentum Mill.) is the second most important vegetable with one of the biggest producing areas worldwide, and an increasing tendency in Hungary as well. To fulfil the growing demands of the industry the producers must use the most suitable genotypes for the

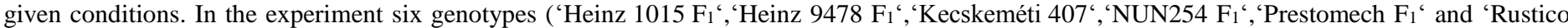
$\left.\mathrm{F}_{1}{ }^{\circ}\right)$ were evaluated for different quality parameters: fruit shape index (length/diameter), firmness $\left(\mathrm{g} \mathrm{cm}^{-2}\right)$, force needed to tear the skin $\left(\mathrm{kg}^{-1}\right)$ and consistency of tomato puree $(\mathrm{g} * \mathrm{sec})$. According to the results, the 'Heinz $1015 \mathrm{~F}_{1}$ ' and 'Heinz $9478 \mathrm{~F}_{1}$ ' were the most suitable genotypes for industrial processing in the mean of fruit quality. Strong positive correlation between consistency of juice and fruit shape index ( $\mathrm{r}=0.891)$ and firmness of berry $(\mathrm{r}=0.882)$ was confirmed. The results have proved the necessity of these quality parameter measurements, which are important for the evaluation of raw material.
\end{abstract}

Tóth, A. R., Tóthné Bogárdi, A., Rubóczki, T., Takácsné Hájos, M. (2020): Rheological evaluation of industrial tomato in raw and processed condition. International Journal of Horticultural Science 26: 60-64. https://doi.org/10.31421/IJHS/26/2020/7922

Key words: industrial tomato, tomato genotypes, rheological evaluation, tomato juice

\section{Introduction}

In Hungary, the industrial tomato is harvested by machine from the beginning of August until the end of September. The most common harvester (Guaresi) has a photoselector which can select the ripen berry by colour. The proper varieties for this process have the following characteristic - firm berries which can ripen at the same time, high lycopene and soluble solids content, resistance/tolerance against disease and pest (Böcs et al., 2011).

Furthermore, the successful production is influenced by proper growing technology - propagation method (direct seeding or by transplant), irrigation method and ecological conditions as natural precipitation, solar radiation, temperature (Helyes et al., 2006). The shape of the berry is important quality parameter as well.

Among the physical parameters the size and the shape of the fruit is important. For mechanical harvest, the proper variety has oblong fruits with 2-3 locular cavities. The internal structure of tomato can influence its mechanical properties, thereby the sensitivity of mechanical damage (Li et al., 2009; Li et al., 2010a; Li et al., 2010b). The physical properties of berry can change during the ripening process. Several studies have proved the clear connection between physical properties of variety and suitability for mechanical harvest (Desmet et al., 2002; Devaux et al., 2005; Linden et al., 2006; Zeebroeck et al., 2007; Li et al., 2010a).These parameters include size and weight of berry, shape, colour and density of fruit. These parameters are important for the proper equipment of harvest (Kilickan \& Guner, 2008).
By the texture analysis of processing tomato, the resistance of fruit can be determine to breakage. The texture of tomato fruits is derived from the turgor pressure, and the composition of plant cell walls and the middle lamella. The cell wall of tomato is mainly consist of cellulose, hemicellulose, pectic substances and proteins. The structure of fruit skin can determine the ability of mechanical harvest. It is an important requirement by industrial tomato breeding. It is known that the tomato harvester and the transport can cause excessive compression on the fruits, therefore the skin resistance of the berry has to be rather high (Ruiz \& Rodriguez, 1983).

Tomatoes have approximately $93-95 \%$ water and 5-7\% total solids. The major texture component of tomato products is the insoluble solids, which are originates from cell walls. This latter can influence the consistency, smoothness, juiciness etc. of fruit tissues (Waldron et al., 2003). The rheological parameters are excellent tools to understand the changing of food structure during processing. Therefore, this is the main reason to follow the changes in the raw material to determine its acceptability for processing (Nindo et al., 2007). The texture of berry is influenced by several factors as cultivar, maturity, growing method and environmental conditions (Barette et al., 1998). For the food industry, the most important parameters are the texture and colour of raw materials (Tijskens \& Evelo, 1994).

The texture of berry can determine the quality of tomato. After harvest, the ripening of the berry is continuous which can result with overripe raw material. This process can cause loss of quality and reduced self-life (Geeson et al., 1985). The quality of the tomato can be characterised by flesh firmness which can 
be tested by destructive deformation test. By this method the recorded force and deformation values can cause change of textural properties determining the raw material. The texture of the fruit is related to wall structure and composition and fruit, furthermore the middle lamella structures (Jackman \& Stanley, 1995).

The softening of the pericarp of berry is the major cause for deterioration of texture. The texture is a proper index for the ripening process, in this way for tomato quality (Frenkel \& Jen, 1989). Požrl et al. (2010) have stated that the textural parameters of tomato were decreased during the storage. Their experiment has proved that the firmness was decreased from $115.52 \mathrm{~N}$ to $31.83 \mathrm{~N}$ by stored at $5^{\circ} \mathrm{C}$, while this value was lower $(19.33 \mathrm{~N})$ by stored at $10{ }^{\circ} \mathrm{C}$. The higher storage temperature $\left(10{ }^{\circ} \mathrm{C}\right)$ reduced the colour intensity of berry.

During fruit maturity, cell wall hydrolytic enzymes contribute to lessening of intercellular adhesion and tissue softening thus tomatoes lose their firmness (Brummel, 2006; Toivonen \& Brummell, 2008). However, the ability of fruit flesh to resist compressive force is an essential feature to estimate fruit ripening and quality. Generally, firmness can be measured by touch or by penetrometer. Both methods are destructive and firmness value can vary greatly depending on the method used and the competence of an executor.

The industrial tomato production has strict requirements for the hybrids - high firmness of berry and soluble solids content. In Hungary, the price of the raw material is depending of the soluble solids content. The minimal requirement is $4.7^{\circ} \mathrm{Brix}$. If the raw material has higher value ( $\left.1^{\circ} \mathrm{Brix}\right)$, the total income can increase by $20 \%$ for the producer.

Important inner quality parameters are soluble solids content and acidity. The organoleptic quality of tomato is measured by water-soluble solids content where $50-65 \%$ of it is di- and monosaccharides (Cuartero et al., 1996). The acidity in the tomato can be explained mainly by citric and malic acids (Nuez, 1995). These parameters can be measured by refractometry, $\mathrm{pH}$ analysis or titratable acidity.

The softening of the fruit flesh can be influenced by degradation of water-soluble pectin content as well. The pectic substances are present in the cell-wall matrix and middle lamellae of berry (Jackman \& Stanley, 1995).

Overall, fruit firmness, total soluble solids and dry matter are essential internal quality attributes of vegetables (Karklelienè et al., 2014; Siddiqui, 2015).

The tomato fruit consists of three types of solids: water and soluble and insoluble. Soluble solids are expressed as degrees Brix ( ${ }^{\circ}$ Brix) and contains mainly sugars (sucrose and fructose) and salts (Beckles, 2011).

The main aim of the experiment was to determine which genotype has the most proper fruit quality parameters for the possibility of mechanical harvest. Furthermore, we want to give information for the processing industry about the evaluated varieties by testing the rheological parameter of tomato juice.

\section{Materials and methods}

The experiment was prepared at the University of Debrecen, Farm and Regional Research Institute, Botanical and Exhibition Garden with open-field technology. The period of the experiment was between $5^{\text {th }}$ of May 2017 (planting date) and 30 ${ }^{\text {th }}$ of August 2017 (harvesting date). Six genotypes (Table 1) were evaluated in the experiment for the following quality parameters - yield (g/plant), fruit shape index (length/diameter), firmness ( $g$ $\mathrm{cm}^{-2}$ ), force needed to tear the skin $\left(\mathrm{kg}^{-1}\right)$ and consistency of tomato puree $(\mathrm{g} * \mathrm{sec})$.

Table 1. Main characteristics of the evaluated genotypes.

\begin{tabular}{c|ccccc}
\hline \multicolumn{1}{c|}{ Genotype } & Origin & $\begin{array}{c}\text { Berry } \\
\text { weight }\end{array}$ & $\begin{array}{c}\text { Vegetation } \\
\text { period }\end{array}$ & $\begin{array}{c}\text { Number } \\
\text { of locule }\end{array}$ & Shape \\
\hline 'Heinz 1015 F ' & USA, Heinz & $75-80 \mathrm{~g}$ & $100-115$ days & 2 & blocky \\
'Heinz 9478 F1' & USA, Heinz & $50-55 \mathrm{~g}$ & $95-105$ days & 3 & oval \\
'Kecskeméti 407' & HU, ZKI & $120-130 \mathrm{~g}$ & $110-120$ days & 3 & $\begin{array}{c}\text { spherical - } \\
\text { slightly flat } \\
\text { spherical - } \\
\text { slightly } \\
\text { oval } \\
\text { 'NUN 254 F' }\end{array}$ \\
'PL, Nunhems & $60-65 \mathrm{~g}$ & $85-90$ days & 3 & $\begin{array}{c}\text { blocky } \\
\text { slightly } \\
\text { oval }\end{array}$ \\
\hline
\end{tabular}

Source: Internet

n.d. - no data

The ecological conditions (Figure 1) and soil parameters (Table 2) were followed during the vegetation period. The data of temperature and precipitation was provided by the Agrometeorological and Agro-ecological Monitoring Centre, Institutes for Agricultural Research and Educational Farm, Farm and Regional Research Institute, University of Debrecen.

The soil of the experiment field was measured by the Agricultural Laboratory Centre, University of Debrecen for the quality parameters.

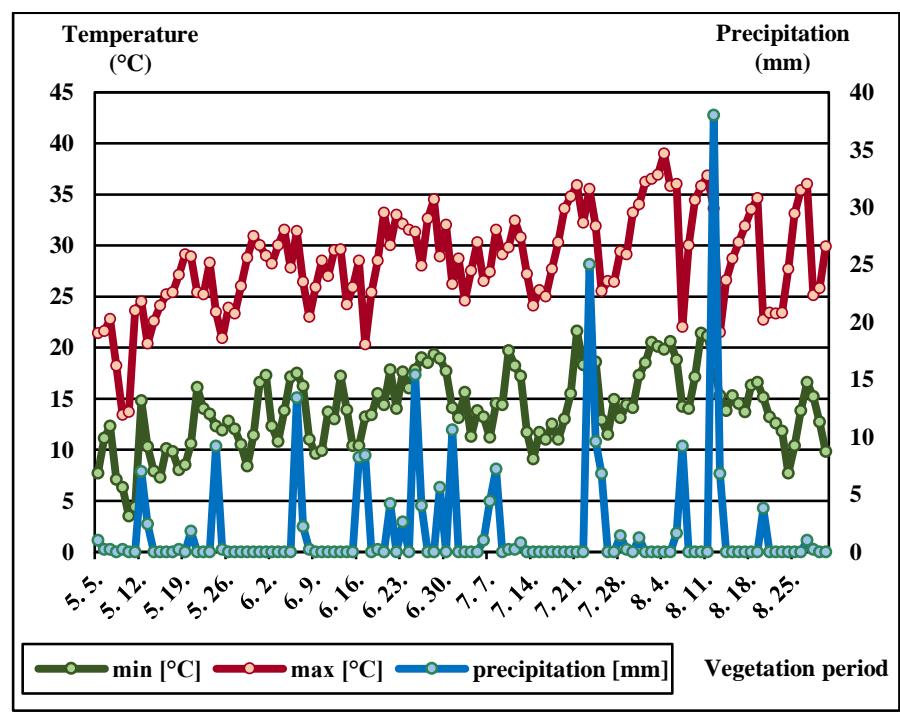

Figure 1. Ecological conditions of the experimental field.

Table 2. Soil analysis of the experimental field

\begin{tabular}{lc}
\hline Soil parameters (unit) & $\mathbf{2 0 1 7}$ \\
\hline $\mathrm{pH}(\mathrm{KCl})$ & 7.09 \\
Plasticity index of Arany $\mathrm{K}_{\mathrm{A}}$ & 37 \\
Total water-soluble salt\% & 0.04 \\
$\mathrm{CaCO}_{3} \%$ & 2.02 \\
$\mathrm{Humus} \%$ & 2.61 \\
$\mathrm{AL}-$-soluble $\mathrm{P}_{2} \mathrm{O}_{5}\left(\mathrm{mg} \mathrm{kg}^{-1}\right)$ & 393 \\
$\mathrm{AL}-$ soluble $\mathrm{K}_{2} \mathrm{O}\left(\mathrm{mg} \mathrm{kg}^{-1}\right)$ & 476 \\
$\mathrm{KCl}-$ soluble $\mathrm{NO}_{3}^{-}+\mathrm{NO}_{2}^{-}-$Nitrogen $\left(\mathrm{mg} \mathrm{kg}^{-1}\right)$ & 12.2 \\
\hline
\end{tabular}


The fruits were hand-harvested at red maturity stage. Physical and mechanical parameters were evaluated for 50 fruits from each genotype.

The firmness of tomato fruits were measured with a Magness-Taylor manual penetrometer. The measurements of the bioyield point and flesh firmness were conducted on a texture analyzer (TA.XTPlus, Texture Technologies Corp., Scarsdale, NY/Stable Micro Systems, Godalming, Surrey, UK) with P/2N probe. The rheological characterization of tomato juice was carried out with the same texture analyser with back extrusion ring $45 \mathrm{~mm}$ disk. The rheological evaluations were conducted at the Institute of Food Science, Faculty of Agricultural and Food Sciences and Environmental Management, University of Debrecen.

\section{Results and discussion}

After the harvest, different tests were taken to examine the quality parameters of the genotypes. The measurements tended to examine the quality and physical parameters of the raw berries and tomato juice. The processing industry requires slightly oval shape berries with two or three locules.

\section{Yield (g/plant)}

Among the economic and quality parameters, the yield plays an important role which can determine the profitability of the genotypes. Therefore, it was investigated in the experiment and expressed as gram per plant (Figure 2).

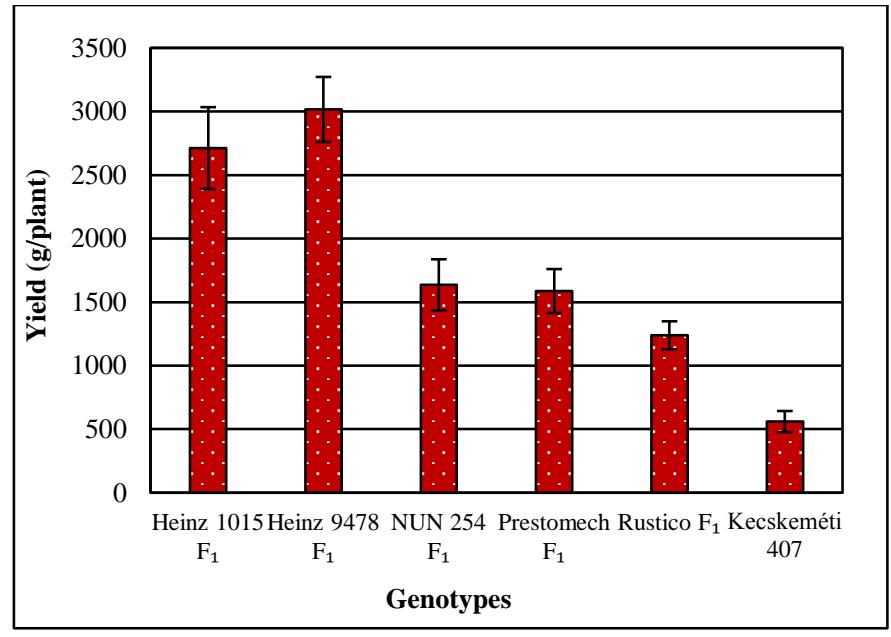

Figure 2. The yield of the evaluated genotypes.

The results show that the leading industrial tomato hybrids, 'Heinz $1015 \mathrm{~F}_{1}$ ' and 'Heinz $9478 \mathrm{~F}_{1}$ ' produced the highest yield (> $2500 \mathrm{~g} /$ plant) which were significant differences. The other genotypes showed much less values for the yield.

\section{Fruit shape index}

The shape of the tomato berry is related with the number of locules of fruit. For the mechanical harvest, slightly oval shape is preferred which can resist high mechanical pressure. Li et al. (2011) have stated that the locule number has effect on certain mechanical parameters such as rupture force of tomato fruits.

The shape index was determined by the length and diameter of the berry. The preferred value is between $1.25-1.35$ for the mechanical harvest. In our experiment we have evaluated 6 genotypes for this parameter (Figure 3).

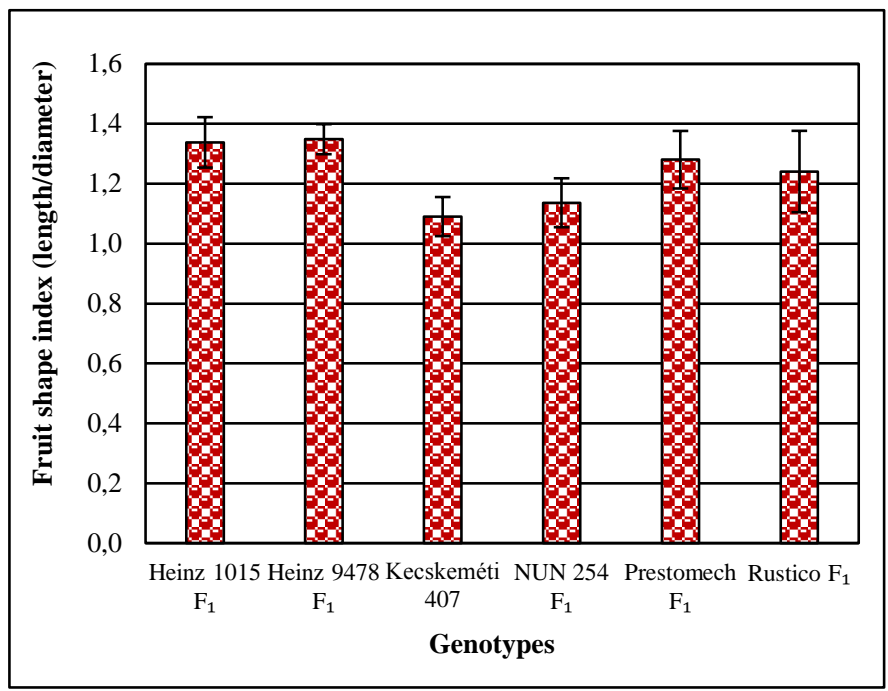

Figure 3. Fruit shape index of different genotypes.

According to the results all of the examined genotypes accomplish the requirements of the industry. The highest fruit shape index belongs to the 'Heinz $9478 \mathrm{~F}_{1}$ ' hybrid (1.35) and 'Heinz $1015 \mathrm{~F}_{1}$ ' (1.34). Similar values were detected by 'Prestomech $F_{1}$ ' (1.28) and 'Rustico $F_{1}$ ' (1.24) hybrids which means that they are suitable for mechanical harvest. Nearly spherical form was observed by 'NUN $254 \mathrm{~F}_{1}$ ' (1.14) and 'Kecskeméti 407‘ (1.09).

\section{Firmness $\left(\mathrm{g} \mathrm{cm}^{-2}\right)$}

The most important requirement of industrial tomato is the possibility of mechanical harvest. In order to fulfil these quests, high firmness is a crucial parameter. The main reason for this requirement is the fact that the berry must be resistant to mechanical impacts during harvesting and transporting. The firmness of berry (Figure 4) is influenced by the stage of ripening and genetic background.

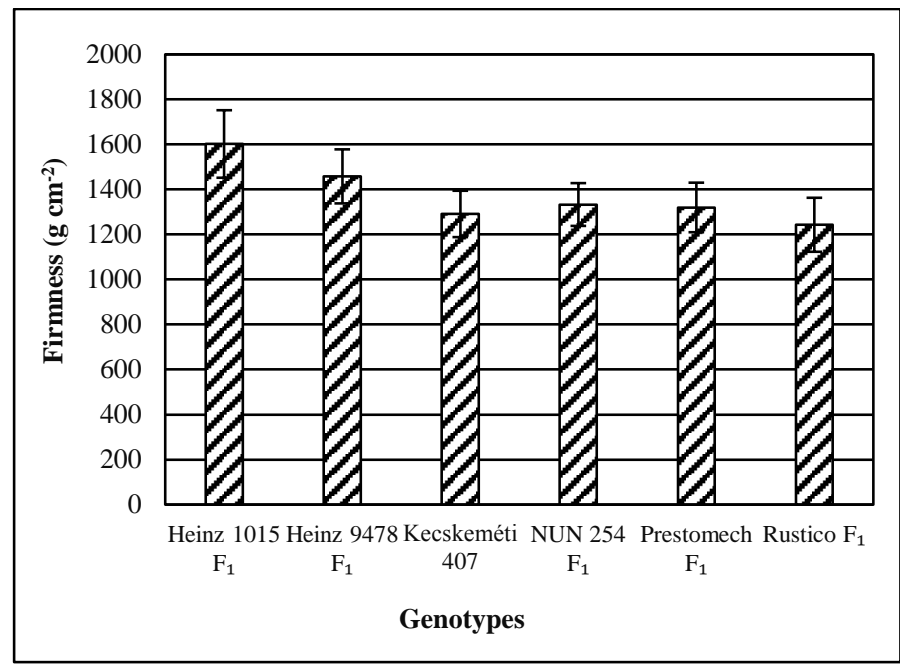

Figure 4. Evaluation of firmness by different genotypes.

According to the results all examined varieties fulfilled the requirements of mechanical harvest, with values higher than $1200 \mathrm{~g} \mathrm{~cm}^{-2}$. The highest fruit firmness was detected in the 
samples of 'Heinz $1015 \mathrm{~F}_{1}$ ' and 'Heinz $9478 \mathrm{~F}_{1}$ ' hybrids (more than $1400 \mathrm{~g} \mathrm{~cm}^{-2}$ ) while the lowest fruit firmness belongs to 'Rustico $\mathrm{F}_{1}$ ' genotype.

\section{Bioyield point}

Rheology is a branch of physics which deals with the deformation and flow of materials, both solids and liquids. The rheological evaluation (Figure 5) shows the force needed to tear the skin (bioyield point). A small cylinder probe was used for the measurements.

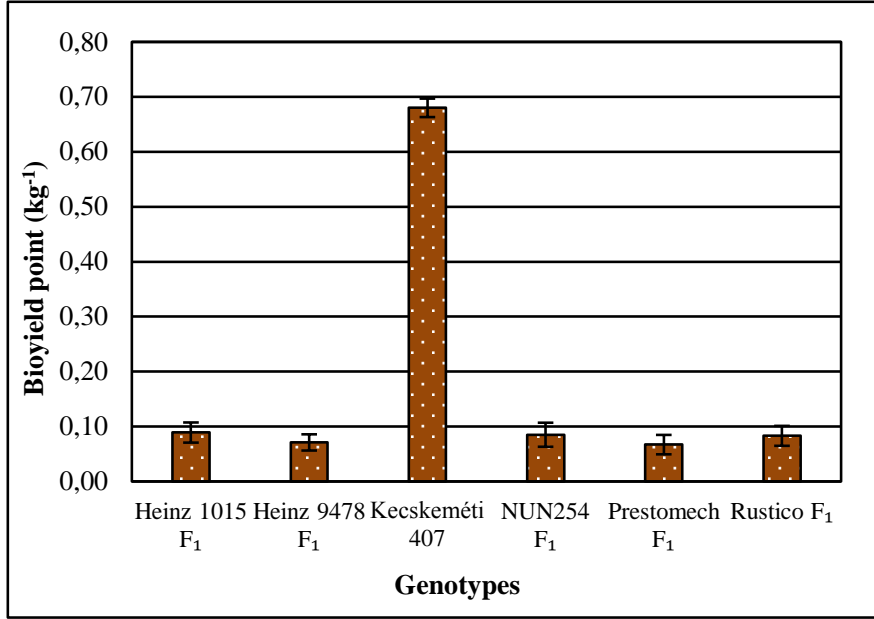

Figure 5. Bioyield point of different genotypes.

According to the results the highest value was measured in 'Kecskeméti 407' variety which showed more than seven times higher values than the other evaluated hybrids. It is a great advantage for mechanical harvest, however during the industrial process it can be a disadvantage because it can increase the waste ratio of the raw material. The five hybrids evaluated in the experiment needed nearly equal force to tear the skin, none of these exceeded $0.01 \mathrm{~kg}$.

\section{Consistency of tomato juice}

With the consistency, the density of the juice can be evaluated. The regulated value was shear speed, with the help of it the shear tensity could be specified. The results are shown in Figure 6.

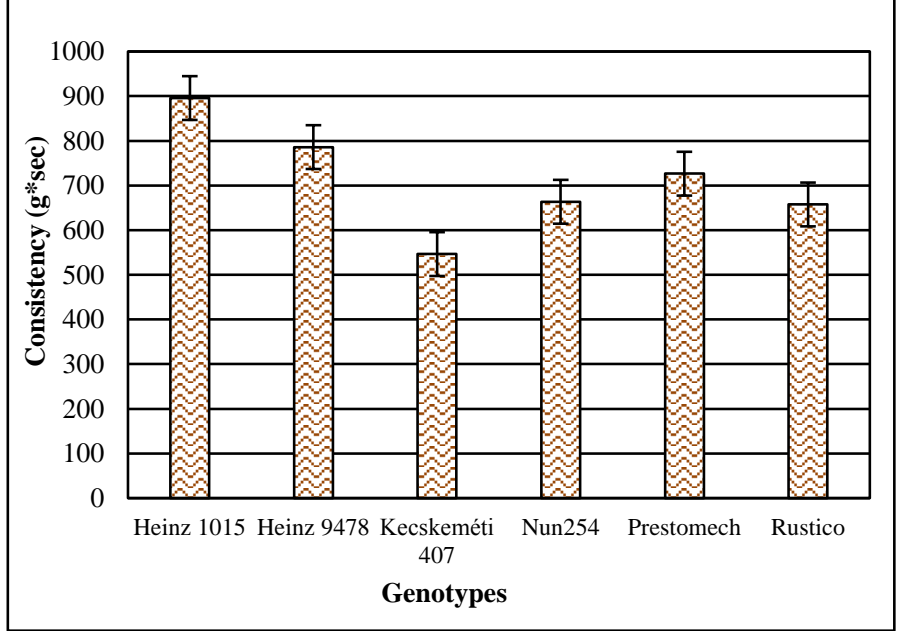

Figure 6. Consistency of tomato juice.
According to the results the 'Heinz $1015 \mathrm{~F}_{1}$ ' and 'Heinz 9478 $\mathrm{F}_{1}$ ' hybrids showed the highest values which means that these juices were the thickest. Compared to the outcome of 'Kecskeméti 407' genotype, which with the lowest value showed the thinnest juice density.

\section{Correlation}

Rather high correlation was found (Table 3) between shape index and consistency $(\mathrm{r}=0.891)$, which was similarly observed in the case of fruit firmness and juice consistency $(r=0.882)$. The proper juice outcome is determined by oval fruit shape (less locules) and firmness of fruit.

Besides this parameter, the slower degradation of pectin content is favourable which can protect the softening of fruit during the ripening process.

Table 3. Relationship between fruit parameters and juice consistency.

\begin{tabular}{|c|c|c|c|c|}
\hline & $\begin{array}{c}\text { Fruit shape } \\
\text { index }\end{array}$ & Firmness & $\begin{array}{c}\text { Bioyield } \\
\text { point }\end{array}$ & $\begin{array}{c}\text { Consistency } \\
\text { of juice }\end{array}$ \\
\hline $\begin{array}{l}\text { Fruit shape } \\
\text { index }\end{array}$ & 0.000 & 0.668 & -0.689 & 0.891 \\
\hline Firmness & & 0.000 & -0.299 & 0.882 \\
\hline $\begin{array}{l}\text { Bioyield } \\
\text { point }\end{array}$ & & & 0.000 & -0.673 \\
\hline $\begin{array}{l}\text { Consistency } \\
\text { of juice }\end{array}$ & & & & 0.000 \\
\hline
\end{tabular}

\section{Conclusions}

It can be concluded, that according to the results in the given conditions the most suitable hybrids for processing are 'Heinz $1015 \mathrm{~F}_{1}$ ' and 'Heinz $9478 \mathrm{~F}_{1}$ ' by the quality parameters and rheological evaluation. According to the results, relationship have been found between the raw material and the consistency of juice. Strict positive correlation between consistency of juice and fruit shape index $(0,891)$ and firmness of berry $(0,882)$ was confirmed. The results have proved the necessity of this quality parameter measurements which are important for the evaluation of raw material.

\section{Acknowledgements}

This study was supported by the EFOP-3.6.3-VEKOP-162017-00008 project. The project is co-financed by the European Union and the European Social Fund.

\section{References}

Barrett, D. M., Garcia, E., Wayne, J. E. (1998): Textural modification of processing tomatoes. Critical Reviews in Food Science and Nutrition. 38(3): 173-258. https://doi.org/10.1080/10408699891274192

Beckles, D. M. (2012): Factors affecting the postharvest soluble solids and sugar content of tomato (Solanum lycopersicum L.) fruit. Postharvest Biology and Technology. 63(1): 129-140. https://doi.org/10.1016/j.postharvbio. 2011.05.016

Bőcs, A., Pék, Z., Helyes, L. (2011): Simultaneous impact of the different water supply and year type on processing tomato yield. International Journal of Horticultural Science. 17(1-2): 79-81. https://doi.org/10.31421/IJHS/17/1-2./950 
Brummell, D. A. (2006): Cell wall disassembly in ripening fruit. Functional Plant Biology. 33(2): 103-119. https://doi.org/10.1071/FP05234

Cuartero, J., Gragera, J., Ruiz, A. (1996): Relación entre los contenidos en sólidos solubles (grados Brix) y azúcares solubles en tomate de industria y lineas silvestres. Agricola Vergel. 15(175): 436-440.

Desmet, M., Lammertyn, J., Verlinden, B. E., Nicolai, B. M., (2002): Mechanical properties of tomatoes as related to puncture injury susceptibility. Journal of texture studies. 33(5): 415-429. https://doi.org/10.1111/j.1745-4603.2002.tb01357.x

Devaux, M. F., Barakat, A., Robert, P., Bouchet, B., Guillon, F., Navez, B., Lahaye, M. (2005): Mechanical breakdown and cell wall structure of mealy tomato pericarp tissue. Postharvest Biology and Technology. 37(3): 209-221. https://doi.org/10.1016/j.postharvbio.2005.04.013

Frenkel, C., Jen, J. J. (1989): Tomatoes. In: Quality and preservation of vegetables. (Ed. Eskin, N. A. M.) CRC Press. Florida. 32-47.

Geeson, J. D., Browne, K. M., Maddison, K., Shepherd, J., Guaraldi, F. (1985): Modified atmosphere packaging to extend the shelf life of tomatoes. International Journal of Food Science \& Technology. 20(3): 339-349. https://doi.org/10.1111/j.13652621.1985.tb00384.x

Helyes, L., Dimény, J., Pék, Z., Lugasi, A. (2006): Effect of the variety and growing methods as well as cultivation conditions on ingredient of tomato (Lycopersicon lycopersicum (L.) Karsten) fruit. Acta Horticulturae. 712: 511-516. https://doi.org/10.17660/ActaHortic.2006.712.62

Jackman, R. L., Stanley, D. W. (1995): Perspectives in the textural evaluation of plant foods. Trends in Food Science \& Technology. 6(6): 187-194. https://doi.org/10.1016/S09242244(00)89053-6

Karklelienė, R., Dambrauskienė, E., Juškevičienė, D., Radzevičius, A., Rubinskienė, M., \& Viškelis, P. (2014): Productivity and nutritional value of dill and parsley. Horticultural Science. $41(3)$ : 131-137. https://doi.org/10.17221/240/2013-HORTSCI

Kılıçkan, A., Güner, M. (2008): Physical properties and mechanical behavior of olive fruits (Olea europaea L.) under compression loading. Journal of Food Engineering. 87(2): 222228. https://doi.org/10.1016/j.jfoodeng.2007.11.028

Li, Z., Liu, J., Li, P., Yin, J. (2009): Study on the collisionmechanical properties of tomatoes gripped by harvesting robot fingers. African Journal of Biotechnology. 8(24): 7000-7007.

Li, Z., Li, P., Liu, J. (2010a): Effect of tomato internal structure on its mechanical properties and degree of mechanical damage. African Journal of Biotechnology. 9(12): 1816-1826. https://doi.org/10.5897/AJB2010.000-3020
Li, Z., Liu, J., Li, P. (2010b): Relationship between mechanical property and damage of tomato during robot harvesting. Transactions of the Chinese Society of Agricultural Engineering. 26(5): 112-116.

Li, Z., Li, P., Liu, J. (2011): Physical and mechanical properties of tomato fruits as related to robot's harvesting. Journal of Food Engineering 103(2): 170-178. https://doi.org/10.1016/j.jfoodeng.2010.10.013

Van Linden, V., De Ketelaere, B., Desmet, M., De Baerdemaeker, J. (2006): Determination of bruise susceptibility of tomato fruit by means of an instrumented pendulum. Postharvest Biology and Technology. 40(1): 7-14. https://doi.org/10.1016/j.postharvbio.2005.12.008

Nindo, C. I., Tang, J., Powers, J. R., Takhar, P. S. (2007): Rheological properties of blueberry puree for processing applications. LWT-Food Science and Technology. 40(2): 292299. https://doi.org/10.1016/j.lwt.2005.10.003

Nuez, F. (1995): El cultivo del tomate. Mundi-Prensa. Madrid, España. pp. 793

Požrl, T., Žnidarčič, D., Kopjar, M., Hribar, J., Simčič, M. (2010): Change of textural properties of tomatoes due to storage and storage temperatures. Journal of Food Agriculture and Environment. 8(2): 292-296.

Ruiz, M., Rodriguez, A. (1983): Variedades de tomate para la recolección mecánica; Ensayos de campo y de laboratorio. In: I. Congreso Nacional de Ciencias Hortıcolas. Valencia, Spain. pp. 789-799.

Siddiqui, M. W. (Ed.). (2015): Postharvest biology and technology of horticultural crops: principles and practices for quality maintenance. CRC Press. USA. pp. 572.

Tijskens, L. M. M., Evelo, R. G. (1994): Modelling colour of tomatoes during postharvest storage. Postharvest Biology and Technology. 4(1-2): 85-98. https://doi.org/10.1016/09255214(94)90010-8

Toivonen, P. M. A., Brummell, D. A. (2008): Biochemical bases of appearance and texture changes in fresh-cut fruit and vegetables. Postharvest Biology and Technology. 48(1): 1-14.

https://doi.org/10.1016/j.postharvbio.2007.09.004

Waldron, K. W., Parker, M. L., Smith, A. C. (2003): Plant cell walls and food quality. Comprehensive reviews in food science and food safety. 2(4): 128-146. https://doi.org/10.1111/j.1541-4337.2003.tb00019.x

Van Zeebroeck, M., Van Linden, V., Darius, P., De Ketelaere, B., Ramon, H., Tijskens, E. (2007): The effect of fruit properties on the bruise susceptibility of tomatoes. Postharvest Biology and Technology. 45(2): 168-175. https://doi.org/10.1016/j.postharvbio.2006.12.022 